\title{
TINJAUAN KEBIJAKAN PERTAHANAN INDONESIA DI KEPULAUAN NATUNA DIHADAPKAN DENGAN PERKEMBANGAN PEMBANGUNAN PANGKALAN MILITER CHINA
}

\author{
Muhammad Achyar, I Wayan Midhio, Khaerudin \\ Fakultas Strategi Pertahanan, Universitas Pertahanan Republik Indonesia \\ Email: achyar2000@gmail.com,midhio_2003_iwayan@yahoo.com,
}

\begin{abstract}
Abstrak
Globalisasi dan perkembangan lingkungan strategis juga telah merubah industri pertahanan dan pasarnya. Keduanya menyesuaikan diri dengan perlucutan senjata ketika Perang Dingin berakhir dan terjadi revolusi dalam aspek militer dan keuangan dalam tatanan global. Perubahan teknis lebih lanjut mempengaruhi industri senjata dan ancaman baru terorisme internasional. Tujuan Penelitian ini adalah untuk menganalisis strategi dan kendala kebijakan pertahanan Indonesia dalam merespon perkembangan pembangunan pangkalan Militer China di Laut China Selatan. Data didapatkan melalui studi literatur dan wawancara terhadap narasumber, kemudian dianalisis menggunakan metode kualitatif dengan Teknik Triangulasi. Hasil penelitian ini dapat disimpulkan bahwa strategi pertahanan Indonesia dengan membentuk Satuan TNI Terintegrasi yang memiliki kemampuan melaksanakan operasi Trimatra dalam menghadapi agresivitas China di Laut China Selatan belum terjabarkan secara konkrit dan komrprehensif, di sisi lain kendala kebijakan pertahanan Indonesia yang terbesar adalah adanya ego dan perbedaan kepentingan diantara para pemangku kebijakan, solusinya perlu komitmen dari Kemhan, Mabes TNI, Angkatan hingga Kotama untuk setia berpegang pada perencanaan yang aplikatif dan teruji.
\end{abstract}

Kata Kunci: Strategi Pertahanan; Kebijakan Pertahanan Indonesia; Laut China Selatan

\begin{abstract}
Globalization and the development of the strategic environment have also changed the defense industry and its markets. Both adapted to disarmament when the Cold War ended and there was a military and financial revolution in the global order. Further technical changes affect the arms industry and new threats of international terrorism. The purpose of this study is to analyze the strategies and constraints of Indonesia's defense policy in responding to the development of China's military base construction in the South China Sea. The data were obtained through literature studies and interviews with informants, then analyzed using qualitative methods with triangulation techniques. The results of this study can be concluded that Indonesia's defense strategy by forming an Integrated TNI Unit which has the ability to carry out Trimatra operations in dealing with China's aggressiveness in the South China Sea has not been described in a concrete and comprehensive manner, on the other hand the biggest obstacle to Indonesia's
\end{abstract}


defense policy is the existence of ego and differences in interests. Among policy makers, the solution requires commitment from the Ministry of Defense, TNI Headquarters, the Armed Forces to Kotama to faithfully adhere to applicable and tested plans.

Keywords: Defense Strategy, Indonesian Defense Policy, South China Sea

Diterima: 19-11-2021

Direvisi: 12-12-2021

Diterbitkan: 20-12-2021

\section{Pendahuluan}

Kompleksitas ancaman yang semakin meningkat dan diikuti perubahan kemajuan teknologi pertahanan yang begitu cepat menandai adanya era globalisasi, telah mendorong banyak negara untuk meningkatkan dan memperkuat kapasitas senjatanya. Modernisasi sistem persenjataan primer atau yang biasa dikenal dengan Alutsista, berperan penting bagi kekuatan pertahanan suatu negara (Ibrahim \& Akhmad, 2014). Modernisasi persenjataan merupakan proses yang kompleks, yang mencakup perubahan kapasitas material untuk mencapai semua tujuan strategis Negara.

Globalisasi dan perkembangan lingkungan strategis juga telah merubah industri pertahanan dan pasarnya. Keduanya menyesuaikan diri dengan perlucutan senjata ketika Perang Dingin berakhir dan terjadi revolusi dalam aspek militer dan keuangan dalam tatanan global. Perubahan teknis lebih lanjut mempengaruhi industri senjata dan ancaman baru terorisme internasional.

China merupakan salah satu Negara dengan modernisasi militer yang secara konsisten terus dikembangkan. Setelah AS dan Rusia, kekuatan militer China yang potensial berada di peringkat 3 dari 138 negara-negara dunia yang dipertimbangkan 'sempurna' untuk tahun 2020 menurut riset Global Firepower. Kekuatan ini dipertimbangkan berdasarkan kapasitas militer, keuangan hingga kemampuan logistik dan geografi China (Firepower, 2020).

Pengembangan kapasitas militer China tidak terlepas dari latar belakang China yang menjadi negara yang pertumbuhan ekonomi tercepat di muka bumi. Namun begitu, pertumbuhan ekonomi ini menimbulkan berbagai tantangan domestik bagi China, mencakup penyeimbangan pertumbuhan populasi dengan sumber daya alamnya, ketidakseimbangan pendapatan yang terus melambung serta peningkatan polusi yang cukup substansial diseluruh China. Dengan demikian, untuk mengamankan kepentingan Negaranya, China melakukan modernisasi militer dalam skala besar.

Pengembangan kapasitas militer umumnya dilakukan tidak hanya untuk meningkatkan keamanan Negara namun juga untuk mencapai national objectives lainnya. Pengembangan kemampuan angkatan laut China tentu tidak terlepas dari kepentingan Negaranya di sejumlah wilayah perairan. Salah satunya di Laut China Selatan. Selama bertahun-tahun China telah membangun pulau dan terumbu karang untuk menjadi pangkalan militer hingga pangkalan pesawat terbang (Sinuhaji, 2020). China membangunan pangkalan militernya di area Laut China Selatan dilakukan demi menjaga 
klaimnya terhadap 80 persen Laut China Selatan yang mempunyai potensi sumber daya yang tinggi terutama minyak dan gas (Raihana, n.d.).

Dunia internasional mengetahui bahwa Laut China Selatan sebagai salah satu jalur perdagangan dunia yang yang sangat penting di sektor logistik. Laut China Selatan beradai di sub-wilayah ekonomi strategis di kawasan Indo-Pasifik. Di tahun 2016, CFR Global Conflict Tracker melansir bahwa perdagangan yang melalui jalur Laut China Selatan besarnya di atas tiga triliun dolar Amerika Serikat. Sementara itu, di tahun 2017, komoditas gas alam cair diperdagangkan empat per sepuluh dari total kebutuhan secara global (Purba et al., 2020).

Sementara di Perairan Natuna, yang merupakan wilayah Republik Indonesia yang menjadi perbatasan langsung dengan Laut China Selatan, dalam beberapa penelitian, daerah yang luasnya lebih dari seratus empat puluh kilometer persegi ini disebut sebagai daerah penghasil gas alam terbesar di dunia.

Di Kepulauan Natuna, potensi gas alam recoverable diperkirakan 46 TCF yang jumlahnya setara 8.383 miliar barel minyak. Total keseluruhan, bila dihitung dengan minyak bumi, ada kurang lebih setengah milyar barel cadangan energi yang ada di blok Natuna. Perhitungan itu berdasarkan jumlah volume, namun jika dikonversi dengan nilai yang berlaku, sumber daya migas Natuna yang nilainya enam ribu triliun. Nilai tersebut berdasar perkiraan harga rata-rata minyak bumi dalam kurun eksploitasi yakni USD 75 per barel dengan nilai tukar Rp 10.000 per dolar Amerika Serikat. Nilai kekayaan ini sangatlah besar apabila dibanding dengan pendapatan negara dalam Anggaran Pendapatan dan Belanja Negara (APBN) tahun 2015 berjumlah berkisar Rp 1.700 triliun (Arafat, 2018).

Dengan demikian, maka menjadi rasional apabila beberapa pakar melakukan klaim kawasan ini mempunyai cadangan energi terbesar di dunia dan wilayah perairan Natuna berupaya diduduki dengan tujuan salah satunya yakni untuk mengamankan kekayaan sumber daya alam tersebut melalui klaim Nine Dash Line. Nine Dash Line ialah sembilan titik imajiner yang berawal dari Pulau Spratly di tengah Laut China Selatan, kemudian diklaim sebagai wilayah Zona Ekonomi Eksklusif bagian dari negara China. Sembilan titik imajiner yang dinamai Nine Dash Line ini yang mendasari China dalam melakukan klaim hampir 90 persen wilayah Laut China Selatan dengan dasar historis. Dasar historis tersebut disusun secara sepihak oleh China tanpa adanya persetujuan konvensi hukum laut internasional di bawah PBB atau United Nation Convention of the Law of the Sea (UNCLOS) 1982 di mana China merupakan negara yang ikut menandatanganinya (Syahriyanto, 2021).

Dalam menghadapi isu pelanggaran perbatasan ini, Indonesia telah menegaskan bahwa Kepulauan Natuna (yang mana menurut China masuk ke dalam klaim Nine Dash Line) berada di kawasan Indonesia berdasar pada keputusan UNCLOS 1982 atau Hukum Laut Internasional PBB yang pengesahannya di tahun 1982. Meski demikian, pelanggaran wilayah perbatasan masih sering terjadi di wilayah tersebut.

Terlepas dari sisi potensial wilayah Natuna Utara, mempertahankan kedaulatan wilayah Negara mutlak perlu dilakukan. Kedaulatan merupakan komponen penting dari 
keberlangsungan eksistensi suatu Negara. Kedaulatan Negara bukan hanya konsep hukum, namun juga terkait erat dengan kemampuan praktis yang dimiliki suatu negara di dalam wilayahnya. Semakin kuat suatu Negara, semakin ia akan memiliki kedaulatan praktis untuk mempertahankan dan memajukan kepentingannya baik di dalam maupun di luar wilayahnya (Harrison \& Boyd, 2018). Bagaimanapun kedaulatan praktis suatu Negara merupakan elemen penting yang terkait erat dengan efektivitasnya sebagai sebuah Negara.

Pada penelitian sebelumnya yang ditulis oleh Kiki Rizky Laila Winarto dengan judul "Respon Indonesia Menghadapi Ancaman China Di Perairan Natuna" menyatakan bahwa Era Pemerintahan Jokowi kebijakan terhadap ancaman China di perairan Natuna direspon melalui peningkatan kapabilitas militer dan diplomasi (Winarto, n.d.). Peningkatan kapabilitas militer bertujuan untuk melindungi hak berdaulat Indonesia di ZEEI perairan Natuna dari pelanggaran-pelanggaran kapal nelayan asing maupun klaim China yang didasarkan pada sembilan garis putus-putus yang berhimpit dengan wilayah perairan Natuna.

Pada penelitian tersebut hanya dipaparkan mengenai respon Pemerintah Indonesia dalam menghadapi permasalahan di Natuna secara umum. Sementara pada penelitian ini akan dipaparkan secara spesifik mengenai strategi dan kendala kebijakan pertahanan Indonesia dalam merespon perkembangan pembangunan pangkalan Militer China di Laut China Selatan.

\section{Metode Penelitian}

Penelitian ini menggunakan metode deskriptif kualitatif dimaksudkan dalam memberi gambaran; ringkasan berbagai kondisi; situasi; realitas sosial; dan berusaha menariknya sebagai suatu ciri; karakter; sifat; model; tanda; serta gambaran tentang kondisi dan situasi pada fenomena tertentu (Bungin, 2007). Desain penelitian ini dilakukan dengan menganalisis kebijakan pertahanan Indonesia khususnya di Kepulauan Natuna, menimbang perkembangan pembangunan pangkalan militer China di Laut China Selatan yang semakin kompleks.

Sementara pengambilan data dalam penelitian ini dilakukan bersifat eksplorasi. Penelitian ini akan menyelidiki secara kritis bagaimana perkembangan modernisasi militer China di Laut China Selatan, pelanggaran perbatasan di Laut Natuna Utara dan kebijakan pertahanan Indonesia di perbatasan, khususnya di Laut Natuna Utara, yang mana penting sebagai wajah pembangunan suatu negara (Lawangan, 2019). Sebagai metode pengumpulan data, data didapatkan melalui studi literatur dan wawancara terhadap narasumber, kemudian dianalisis menggunakan metode kualitatif dengan Teknik Triangulasi.

\section{Pembahasan}


Kegiatan penelitian dilaksanakan di Kementerian Pertahanan Republik Indonesia, dengan melengkapi data di Mabes TNI, Mabesau, dan Koarmada 1, dengan tujuan penelitian untuk menghasilkan analisis terkait strategi pertahanan Indonesia dalam merespon perkembangan pembangunan pangkalan Militer China di Laut China Selatan dan kendala-kendala yang timbul.

Sebagai dasar dalam menganalisis strategi pertahanan Indonesia dalam merespon perkembangan pembangunan pangkalan militer China di Laut China Selatan, dapat dilihat sejak China mengumumkan klaim kedaulatan yang cukup luas di wilayah Laut China Selatan pada tahun 2009, wilayah tersebut semakin lama semakin termiliterisasi seiring Beijing berusaha untuk melegitimasi dan berupaya mempertahankan klaimnya. Klaim kedaulatan China atas laut China Selatan tidak terlepas dari sumber daya alam yang kaya yang terdapat di Laut China Selatan serta letak Laut China Selatan yang strategis, berada di jalur perdagangan internasional. Hal tersebut menjadikan China membangun kekuatan ofensif di wilayah tersebut dan di saat yang sama kemudian menimbulkan kekhawatiran serta meningkatkan dilema keamanan di Kawasan.

Diketahui bahwa pembangunan kekuatan di Laut China Selatan telah menjadi yang paling aktif dengan berbagai indikator kekuatan, seperti kuantitas dan kualitas senjata yang telah dikerahkan, reklamasi tanah yang dilakukan serta fasilitas militer yang dibangun atau ditingkatkan di pos-pos yang disengketakan. Sebagaimana disampaikan oleh Kepala Sub Direktorat Amerika dan Pasifik, Direktorat Kerjasama Internasional Pertahanan, instalasi struktur pangkalan militer yang telah dibangun China di tiga pulau yaitu, Woody Island, Mischief Reef dan Fiery Cross Island bersifat permanen.

Di Pulau Fiery Cross misalnya, saat ini terdapat sebuah landasan pacu sepanjang 3.125 meter dan situs radar peringatan dini terkait. Menurut Pusat Studi Strategis dan Internasional, pembangunan pangkalan militer ini merupakan pangkalan militer China yang paling maju, tepat di wilayah yang disengketakan di Laut China Selatan, dengan 12 tempat perlindungan yang diperkeras dengan atap yang dapat dibuka untuk meluncurkan rudal seluler yang suda selesai dibangun.

Selain itu, pangkalan militer ini memiliki hangar yang cukup untuk menampung 24 pesawat tempur dan empat pesawat yang lebih besar. Fiery Cross Reef saat ini memiliki landasan yang cukup panjang untuk mendaratkan pesawat pengebom Xian H-6N China. Pengebom seperti ini dapat melakukan operasi tempur dalam jarak 5.600 kilometer atau setara dengan 3.500 mil dari terumbu yang direklamasi.

Pembangunan artificial island di Kepulauan Spratly dan Paracel hingga saat ini sudah membangun forward operating base yang dengan kemampuan Rudal Jelajah anti kapal dan rudal anti udara lengkap dengan kemampuan Gudang Penyimpanan, radar dan sensor sebagaimana yang disampaikan Staf Operasi Koarmada I, China juga secara konstant melakukan pengerukan di sekitar fasilitas labuhnya, sehingga saat ini kapalkapal dengan draft yang lebih dalam bisa berlabuh. Selain kemampuan resupply dan maintenance bagi kapal-kapalnya, Pelabuhan milik China di Laut China Selatan juga dilengkapi dengan kemampuan intellegence, surveillance dan reconnaissance (ISR), hingga saat ini aktifitas yang dilakukan oleh China di Laut China Selatan diketahui dalam 
bentuk pengerahan kekuatan PLA (People's Liberation Army) Angkatan Laut, China Coast Guard (CCG), serta nelayan milisi secara agresif, China saat ini secara rutin melaksanakan tindakan mata-mata terhadap setiap kapal yang melintasi LCS.

China juga mengeluarkan peraturan-peraturan secara sepihak, seperti aturan penangkapan ikan, menjaga lingkungan maritim, membangun dua Kawasan distrik baru China di Pulau Paracel dan Pulau Spratly, wajib lapor kapal-kapal Perang, Kapal Selam, Kapal Pengangkut Bahan Kimia, Kapal mata-mata, Kapal Pengangkut Gas dan minyak serta kapal-kapal yang dicurigai oleh aparat maritim China, serta melanjutkan pembangunan pulau-pulau buatan di wilayah Laut China Selatan, yang dimiliterisasi menjadi pos-pos militer, disamping itu China juga telah merebut dan mengklaim fiturfitur laut yang berada dibawah permukaan air laut dari negara-negara klaiman di Laut China Selatan.

Dalam konteks global saat ini ancaman terhadap kedaulatan negara telah berkembang sejalan dengan perkembangan teknologi. Teknologi pertahanan selalu dianggap mewakili kekinian karena senantiasa didorong oleh kemampuan penangkalan untuk dapat menjawab tuntutan dan merespon ancaman yang selalu berubah. Oleh karena itu, produk pertahanan selalu menjadi state of the art.

Dalam konteks tersebut, suatu negara yang memiliki industri pertahanan yang mapan dianggap memiliki sebuah keuntungan strategis dalam tatanan global (Kina Media Ekuitas Produk Indonesia, 2012:6). Kondisi ini membuat Indonesia memerlukan sistem dan alutsista pendukung pertahanan yang dapat menghadapi berbagai potensi ancaman yang akan muncul.

Sebagai kaitan dengan state of the art, Pertahanan Indonesia mengatur dan merancang strategi khusus untuk merespon perkembangan pembangunan pangkalan militer China di Laut China Selatan, salah satunya ialah dengan membentuk Satuan TNI Terintegrasi yang memiliki kemampuan melaksanakan operasi Trimatra dalam menghadapi agresivitas China di Laut China Selatan.

\section{Strategi pertahanan Indonesia dalam merespon perkembangan pembangunan pangkalan militer China di Laut China Selatan}

Realisme dalam Hubungan Internasional digunakan untuk menganalisis perkembangan pembangunan pangkalan militer China dan motivasi yang mendorong China untuk melakukan klaim di Laut China Selatan dalam bentuk Nine Dash Line. Karena itu secara realistis China memperkuat militernya untuk mengantisipasi ancaman di masa depan dalam bentuk rangkaian rantai kepulauan yang menjadi pertahanan China di Laut China Selatan dan Samudera Pasifik, China sejak kemenangan Partai Komunis dan berdirinya Republik Rakyat China memandang Amerika Serikat sebagai negara yang secara ideologi bertentangan dengan China dan menjadi ancaman utama China, sehingga sejak awal sudah mempersiapkan strategi Island Chain untuk membentuk sistem pertahanan pada pulau-pulau di luar daratan utama China sebagai garis pertahanannya, tahap pertama China berusaha memperkuat pengaruhnya pada daerah-daerah yang masuk 
pada first island chain dan berturut turut mengembangkannya menuju ke second island chain.

Laut China Selatan merupakan area yang termasuk di dalam first island chain, secara realistis ini membawa China pada keputusan untuk memperkuat klaimnya dengan menduduki dan meningkatkan kehadirannya di Laut China Selatan, sehingga bagi China pembangunan pangkalan militer China merupakan langkah strategis dan logis yang harus ditempuh China dalam mempersiapkan pertahanannya, hal ini sesuai dengan teori realisme dalam dunia internasional, bahwa asumsi realisme yang digunakan ada pada lingkungan internasional yang anarki menciptakan security dilemma yang mendorong negara-negara untuk memiliki kemampuan self-help/self-defense menuju capacity building dari bangsa tersebut. Keputusan yang bagi China strategis dan logis ini kemudian memberikan dampak bagi negara-negara yang berada di sekitar Laut China Selatan, bahwa klaim dan pembangunan pangkalan militer China di Laut China Selatan membawa dampak serius yang mendorong kehadiran militer asing di luar Kawasan dalam hal ini Amerika Serikat beserta sekutunya untuk hadir di Laut China Selatan.

Pertanyaan logis selanjutnya yang kemudian hadir adalah apakah negara-negara yang berada di Laut China Selatan menyadari potensi konflik yang mungkin terjadi di Laut China Selatan dan bagaimana respon dari negara-negara tersebut. ASEAN sebagai organisasi bagi bangsa-bangsa di Asia Tenggara terbelengu dengan kebijakan "ASEAN Way" yang memegang tegus prinsip non intervensi dan konsesus sehingga ASEAN sebagai suatu organisasi tidak memiliki diplomasi kolektif (Maksum, 2017), sehingga dalam memandang China dan klaim nine dash line, negara-negara ASEAN tidak memiliki kesamaan pandangan, Peneliti sendiri menyimpulkan hal yang sama karena hasil wawancara dengan para narasumber dapat disimpulkan bahwa Indonesia sendiri tidak berupaya melibatkan negara-negara ASEAN sebagai bagian dari kebijakan pertahanan Indonesia, padahal harus disadari pendudukan seluruhnya atau sebagian dari teritori negara-negara anggota ASEAN oleh negara lain akan memberikan dampak yang besar baik bagi ASEAN secara organisasi maupun kepada negara-negara anggota termasuk Indonesia.

Kerjasama pertahanan antara negara-negara ASEAN akan sulit terbentuk, menarik hasil penelitian dari Ali Maksum yang menyampaikan bahwa ASEAN yang memegang teguh prinsip non-intervensi dan konsensus malah menjadikan ASEAN menjadi lemah dan dengan mudah dimanfaatkan China, ASEAN pada akhirnya tidak memiliki kesepahaman dalam memandang konflik di Laut China Selatan. China sendiri sebagai negara yang merupakan aktor utama dalam konflik Laut China Selatan, menjadikan pembangunan pangkalan militer China di Laut China Selatan sebagai pilihan rasional China menimbang Laut China Selatan merupakan kawasan strategis dalam aspek sumber daya alam dan berada di posisi jalur perdagangan internasional, dimana secara rasional cepat atau lambat hal ini akan berdampak terhadap kepentingan nasional Indonesia dan seluruh negara ASEAN. Disisi lain Vietnam, Philipina, Malaysia dan Brunei Darussalam memiliki klaim wilayah yang lebih serius di Laut China Selatan, pembangunan pangkalan militer China di kepulauan Spratly, Pulau Woody dan 
Kepulauan Paracel di klaim seluruhnya oleh sebagian oleh negara-negara tersebut, tumpang tindih klaim kewilayahan inilah dan masuknya Amerika Serikat dengan dalih mempertahankan kebebasan navigasi ke dalam perselisihan di Laut China Selatan mendorong peningkatan eskalasi ancaman di Laut China Selatan.

Lalu Strategi apa yang diambil oleh Indoenesia, saat ini Indonesia masih sangat tergantung kepada Alutsista dari luar negeri, terutama jika dikaitkan dengan Alutsista high tech, seperti pesawat tempur, kapal perang, main battle tank, peluru kendali, Radar hingga unmanned aerial vehicle (UAV/Drone). Padahal kemandirian industri pertahanan dan terjaminnya sustainable Alutsista merupakan faktor penting, meskipun Indonesia mungkin memiliki Alutsista bernilai tinggi, modern dan canggih namun ini malah menggambarkan ketergantungan yang besar dari Indonesia terhadap Alutsista dari negara lain. Kesadaran untuk membuat road map terkait industri pertahanan maupun proses pentahapan menuju kemandirian teknologi alutsista masih berjalan di tempat, terbukti hingga saat ini belum ada pencanangan yang jelas kapan kemandirian ini dapat tercapai.

Berdasarkan informasi yang diberikan para narasumber, Peneliti mendapat gambaran bahwa hingga saat ini Indonesia belum memiliki road map dan target jelas modernisasi teknologi dan industri pertahanan, para narasumber tidak mampu menerangkan kapan dan bagaimana caranya Indonesia mencapai kemandirian dalam hal teknologi dan industri pertahanan, tanpa adanya road map dan target yang jelas maka upaya modernisasi teknologi dan industri pertahanan akan berjalan tanpa arah dan cenderung berubah-ubah atau tidak konsisten.

Kebijakan IDKLO (Imbal Dagang, Kandungan Lokal, dan Offset) merupakan upaya yang sudah tepat namun harus dibarengi dengan perencanaan matang dalam bentuk alih teknologi hingga pengembangan riset teknologi dalam upaya membentuk modernisasi, target waktu yang dibutuhkan akan dapat disusun jika Indonesia telah memiliki road map modernisasi teknologi dan industri pertahanan, sehingga evolusi yang dibutuhkan dalam modernisasi dapat tercapai dengan efektif dan juga efisien.

Menurut Carl von Clausewitz, strategi militer mempunyai definisi sebagai kerja pertempuran dalam rangka memenangkan akhir pertempuran. Definisi strategi militer oleh Liddell Hart menyebutkan bahwa strategi ialah seni menyebarkan dan mengimplementasikan cara militer dalam rangka pemenuhan tujuan kebijakan. Sebagai ilustrasi ketika Indonesia akan berperang di Laut China Selatan maka Indonesia berperang dengan cara menguasai Laut dan Udara di Laut China Selatan, untuk mencapai tujuan tersebut maka Indonesia harus memiliki kemampuan untuk menghancurkan kekuatan musuh secara efektif dan efisien, mengetahui secara jelas apa dan bagaimana kekuatan musuh dihancurkan, apakah dengan kekuatan Indonesia sendiri ataukah bekerjasama dengan negara lain, untuk menghancurkan secara efektif dan efisien diperlukan teknologi yang mampu menghubungkan data dan komunikasi antara Angkatan dan diantara alutsista yang terlibat menjadi satu kesatuan pemukul yang bekerja sama menghancurkan musuh, dengan ilustrasi singkat ini Indonesia akan dapat dan baru mempersiapkan dalam skala prioritas alutsista, fasilitas, sarana dan prasaran yang perlu dibangun atau diadakan. 
Berdasarkan hal tersebut dapat disimpulkan bahwa Pertahanan Indonesia masih belum memiliki strategi militer yang jelas dan memadai untuk menghadapi berbagai macam ancaman konflik di Laut China Selatan. Hal ini melengkapi penelitian yang dilakukan oleh M. Bahtiar Fajri yang berjudul "Strategi Pertahanan Maritim Indonesia Di Tengah Dinamika Perang Hibrida Kawasan Laut China Selatan". Dalam penelitian tersebut dinyatakan bahwa cara yang tepat bagi Indonesia untuk merespon dan menangkal ancaman konflik LCS adalah dengan menyusun dan memperkuat strategi pertahanan maritimnya dan membentuk komponen utama melalui restrukturisasi $\mathrm{K} / \mathrm{L}$ berdasarkan Militer, Politik, Ekonomi, Sipil, dan Informasi (MPESI). Strategi ini sangat bergantung pada kekuatan eskalasi dan penggunaan kekuatan militer negara di wilayah sengketa.

Hingga saat ini penelitian ini melengkapi bahwa strategi yang dimaksud masih belum terjabarkan secara konkrit dan komrprehensif. Namun dalam penelitian ini penulis juga akan menjabarkan beberapa hal yang menjadi kendala kebijakan pertahanan Indonesia yang terbesar yakni adanya ego dan perbedaan kepentingan diantara para pemangku kebijakan.

\section{Kendala kebijakan yang dihadapi Indonesia dalam merespon perkembangan pembangunan pangkalan militer China di Laut China Selatan}

Hubungan antara Indonesia dan China atau Indonesia dan Amerika Serikat dan hubungan antara China dengan Amerika Serikat selalu diwarnai dengan kepentingankepentingan yang melatar belakangi hubungan-hubungan tersebut. China atas nama kebanggaan masa lampau sebagai kekaisaran yang menjadi superpower di Asia pada zaman dahulu saat ini kembali menuju ke zaman keemasannya, hingga klaim terhadap wilayah Laut China Selatan dilakukan dengan lebih serius dan masif, hal ini mempunyai perbedaan dengan era tahun ' 80 -an, di mana klaim China tidak ditindak lanjuti dengan pembangunan pangkalan militer di Laut China Selatan. Indonesia sendiri harus menyadari pasang surut hubungan dengan China atau dengan Amerika Serikat dapat dijadikan peluang untuk kepentingan Indonesia, sebagai negara yang memiliki perbatasan dengan Laut China Selatan, Indonesia harus dapat menjamin bahwa China tidak akan pernah melakukan okupasi atau bahkan hanya sekedar pelanggaran wilayah, untuk itu selayaknya negara-negara lainnya, Indonesia harus memiliki kekuatan dan kemampuan militer yang mampu mengatasi kekuatan China di Laut China Selatan.

Kesadaran untuk membuat road map terkait industri pertahanan maupun proses pentahapan menuju kemandirian teknologi alutsista masih berjalan di tempat, terbukti hingga saat ini belum ada pencanangan yang jelas kapan kemandirian ini dapat tercapai. Bahwa Indonesia saat ini belum berhasil terlepas dari ketergantungan dari negara-negara maju dan belum memiliki road map jelas untuk menuju tahap modernisasi yang diidamkan, kondisi ini kemudian diperparah dengan pengadaan Alutsista yang berbagai macam, dimana Indonesia membeli banyak Alutsista dari berbagai negara yang pada akhirnya tidak compatible satu dengan lainnya atau tidak dapat terhubung atau terintegrasi sehingga kemampuan Alutsista ini tidak dapat optimal, tidak seperti India yang berhasil menggabungkan pesawat tempurnya yang terdiri dari berbagai macam pada 
satu jaringan networking atau dalam suatu battle management system yang sama, sehingga dapat bereaksi dengan lebih cepat dan tekoneksi secara optimal, hingga saat ini Indonesia belum mampu melakukan hal ini sehingga mengurangi kemampuan Alutsista yang dibeli dari berbagai negara tersebut.

Indonesia yang menganut sistem pertahanan rakyat semesta, secara narasi sangat bagus dan komprehensif di mana meliputi tatanan segala sektor kekuatan terselenggara seluruhnya, terpadu dan terarah di bawah kesatuan komando dengan mempersatukan strategi pertahanan, sehingga menjadi satu kesatuan pertahanan negara. Dalam rangka berhadapan dengan ancaman militer, penempatan TNI sebagai Komponen Utama dengan dukungan Komponen Cadangan dan Komponen Pendukung dengan suatu mobilisasi berdasarkan ketentuan perundang-undangan.

Namun kendala yang dihadapi adalah belum terujinya sistem ini pada perang modern secara konkrit hingga kini Indonesia belum pernah mengadakan latihan masif yang secara umum menguji sistem pertahanan rakyat semesta ini, pemanfaatan setiap sumber daya yang ada baik militer maupun sipil tidak secara sederhana menggabungkan semua kekuatan mobilisasi dalam suatu "mangkuk", namun perlu pengujian organisasi tugas yang melibatkan setiap komponen bangsa agar dapat bersinergi sehingga sistem pertahanan rakyat semesta dapat berfungsi secara optimal.

Pengujian terhadap konsep atau doktrin sistem pertahanan rakyat semesta yang hingga saat ini belum ada menjadi kendala yang timbul dalam kebijakan pertahanan Indonesia dan menjadi sebab keraguan bahwa sistem ini merupakan jawaban bagi respon pertahanan Indonesia dalam menghadapi perkembangan militer China di Laut China Selatan.

Strategi pertahanan secara umum dikembangkan dalam rangka meraih tujuan pertahanan, salah satunya yakni untuk melindungi kedaulatan dan integritas wilayah. Ambisi China dalam mengejar kepentingan nasionalnya yang tercermin pada peningkatan kemampuan militernya, tentu akan menimbulkan kekhawatiran bagi negara-negara di Kawasan khususnya Indonesia. Menimbang wilayah ZEE Indonesia yang beririsan dengan klaim nine dash line China, kekuatan China di Kawasan secara langsung atau tidak, cepat atau lambat akan berdampak terhadap kedaulatan Indonesia jika Indonesia tidak segera mengembangkan strategi pertahanan yang mampu mengantisipasi berbagai jenis gangguan dan ancaman terhadap integritas dan keutuhan wilayah (Supriyatno, 2014).

Meningkatnya hegemoni dan dinamika terkait teritori di Kawasan khususnya di sepanjang perbatasan Laut China Selatan, membutuhkan analisis mendalam terkait bagaimana mengembangkan dan mengalokasikan kekuatan militer yang mumpuni sehingga meski China sebagai negara yang besar, tetap tidak mampu mengembangkan hegemoninya melewati batas negara Indonesia. Kapal Coast Guard China yang berhasil masuk ke perairan Indonesia adalah cerminan bahwa Indonesia perlu untuk senantiasa mengambil langkah dalam melihat kemungkinan-kemungkinan yang lebih merugikan Indonesia di kemudian hari. 
Langkah yang diambil Indonesia sebagai strategi pertahanan dalam menghadapi perkembangan pangkalan militer di Laut China Selatan yakni Indonesia melakukan pembangunan infrastruktur di Pulau Natuna dan wilayah sekitarnya untuk menegaskan kehadirannya. Selain pembangunan infrastruktur, Indonesia dapat terus meningkatkan kekuatan pasukan melalui operasi gabungan rutin dan modernisasi alutsista. Hal ini dilakukan dengan tujuan agar Indonesia selalu siap ketika se waktu-waktu dibutuhkan untuk melakukan serangan tempur. Selain itu, peningkatan penjagaan dan kekuatan personil di wilayah perbatasan ditujukan untuk meminimalisir adanya pelanggaran perbatasan yang mungkin terulang kembali. Langkah (ways) lain yang diambil sebagai formulasi strategi pertahanan, yakni mengembangkan diplomasi konstruktif terhadap negara-negara di kawasan. Dengan melihat adanya hegemoni di tengah-tengah kawasan yang sewaktu-waktu dinilai sebagai ancaman bersama, cara pandang yang sama antar negara-negara di kawasan terhadap peningkatan hegemoni tersebut, dapat menumbuhkan rasa dalam membangun sikap saling percaya (confidence building measures) dalam memperkuat diplomasi pertahanan antar Negara-negara di kawasan Asia Tenggara, yakni salah satunya melakukan latihan militer bersama secara konstan.

Berbagai tindakan tersebut merupakan cara-cara (ways) yang diambil Indonesia sebagai bagian dari formulasi strategi pertahanan Indonesia dalam menghadapi dinamika di kawasan. Sementara sumber daya (means) yang dikerahkan yakni kekuatan personil gabungan dan kualitas personil yang terus ditingkatkan serta alutsista siap tempur yang dipersiapkan. Langkah-langkah dan sumber daya tersebut diupayakan untuk mencapai tujuan strategi pertahanan, yakni keutuhan wilayah dan kepentingan nasional.

Salah satu contoh belum dioptimalkannya sumber daya yang ada di Natuna adalah pemanfaatan nelayan-nelayan Indonesia sebagai milisi atau komponen cadangan yang dilatih sejak awal untuk ikut menjaga kedaulatan negara dan kepentingan nasional di Laut Natuna Utara, padahal potensi nelayan-nelayan Indonesia sebagai bagian dari Bela Negara dalam membantu Pertahanan Negara untuk mendukung tugas dari Komponen Utama yaitu TNI, Negara seperti China telah sejak lama mendayagunakan milisi nelayannya untuk turut menjaga kehadiran di lokasi yang diperseketakan di Laut China Selatan, kendala yang mungkin dihadapi meliputi anggaran pelatihan dan pengadaan peralatan namun investasi ini jauh lebih murah daripada ketika Indonesia kehilangan sumber daya di Zona Ekonomi Eksklusif atau yang lebih parah kehilangan wilayahnya.

Dalam strategi pertahanan tersebut, ditemui beberapa kendala seperti pembangunan kekuatan tri matra terpadu dengan satuan TNI terintegrasi belum terjabarkan secara konkrit dan nyata serta belum dapat mengatasi atau bahkan mengimbangi kekuatan ancaman dari China. Selain itu, belum adanya konsistensi dalam pengadaan Alutsista juga menjadi kendala dalam strategi pertahanan Indonesia, selain itu pengadaan alutsista belum didasari dengan cara (ways) yang akan digunakan dan berasal dari berbagai macam negara, sehingga Alutsista yang dimiliki sulit terkoneksi baik komunikasi maupun data. Sebagaimana diketahui perencanaan pengadaan Alutsista ini sering berubah di tengah jalan, sehingga tidak dapat dikatakan strategi yang berkesinambungan. Padahal strategi merupakan jalan untuk mencapai tujuan, untuk itu 
hal paling utama adalah menentukan tujuan (ends) yang konsisten, yaitu terjaganya kedaulatan dan kepentingan Indonesia di Laut Natuna Utara dapat tercapai, kemudian menyusun ways atau cara dan terakhir melengkapi means atau sumber daya yang mendukung pelaksanaan ways.

\section{Kesimpulan}

Strategi Pertahanan Indonesia dalam merespon perkembangan pembangunan pangkalan militer China di Laut China Selatan dapat dijelaskan dalam tiga hal yaitu, Pertama, ASEAN dan Benturan Kepentingan di Laut China Selatan. ASEAN sebagai organisasi negara-negara Asia tenggara diharapkan menjadi bagian dari strategi pertahanan Indonesia dalam mengantisipasi potensi konflik bersenjata di Laut China Selatan.

Kedua, Modernisasi Pertahanan. Modernisasi Pertahanan Indonesia dibandingkan dengan analisis akan modernisasi militer China diharapkan dapat menjadi tolak ukur bagi Indonesia dalam rangka pengembangan kekuatan pertahanan yang berkesinambungan dalam upaya menghadapi berbagai gangguan dan ancaman. Terlebih dalam memahami isu perbatasan di Wilayah Laut Natuna Utara, Indonesia harus selalu hadir di Laut Natuna Utara.

Ketiga, Sistem Pertahanan Indonesia. Sistem Pertahanan yang digunakan Indonesia dalam bentuk sistem pertahanan rakyat semesta, sedangkan dalam menghadapi ancaman di Laut China Selatan, Indonesia membentuk Satuan TNI Terintegrasi, suatu konsep satuan yang memiliki kemampuan untuk melaksanakan operasi tri matra, namun demikian pembangunan atuan TNI Terintegrasi yang dilengkapi dengan sarana dan prasarana pendukung perlu untuk melihat bentuk dari modernisasi militer China yang cepat atau lambat akan berdampak terhadap pertahanan Indonesia di saat ini dan di masa mendatang. Implementasi dari kebijakan memperkokoh pertahanan laut dan udara ditempuh dengan berbagai strategi.

Konsep terpadu mengindikasikan penanganan Laut Natuna Utara yang komplek tidak bisa sekedar ditangani oleh kekuatan TNI dan kesiagaan alutsistanya 24/7 namun perlu diintegrasikan dengan kerja sama kekuatan dan kemampuan lainnya dari lembaga dan kementerian terkait.

Kendala kebijakan yang dihadapi Indonesia dalam merespon perkembangan pembangunan pangkalan militer China di Laut China Selatan dapat dijelaskan dalam tiga hal, yaitu: Pertama, ASEAN dan Benturan Kepentingan di Laut China Selatan. ASEAN belum dapat memiliki kolektifitas dalam menghadapi ancaman dari luar ASEAN, kuatnya pengaruh negara-negara kuat yang lebih maju dan kaya melunturkan solidaritas di kalangan negara-negara ASEAN, secara singkat dapat disimpulkan bahwa ketika terjadi konflik bersenjata menimpa salah satu negara ASEAN maka negara ASEAN lainnya tidak memiliki kewajiban untuk mempertahankan atau membantu dengan kekuatan militer, pada akhirnya jika kendala ini tidak berhasil dipecahkan akan berdampak pada lunturnya nilai-nilai solidaritas di kalangan negara-negara ASEAN berganti dengan kepentingan dari negara-negara kuat yang lebih maju dan kaya. 
Kedua, Modernisasi Pertahanan. Modernisasi pertahanan Indonesia menemukan faktor kendala yang paling krusial yaitu pada egosentris dan benturan kepentingan yang terjadi di antara pemangku kepentingan, keterbatasan yang secara umum diketahu sebagai kendala pokok ternyata bukan menjadi suatu kendala, karena solusi atau jawaban dari kendala keterbatasan anggaran sudah ditemukan dalam penyusunan Minimum Essential Force (MEF), MEF disusun dengan maksud untuk melakukan efisiensi dengan anggaran yang etrsedia namun kekuatan sudah mampu mengatasi ancaman yang mungkin timbul. Namun egosentris dan perbedaan kepentingan antara pemangku kepentingan yang hingga saat ini belum mendapat jawabannya.

Ketiga, Sistem Pertahanan Indonesia. Sistem Pertahanan Indonesia yang menganut Sistem Pertahanan Rakyat Semesta dalam mempertahankan kedaulatan dan wilayah serta kepentingan nasionalnya dengan cara menggunakan seluruh sumber daya dan kekuatan rakyat serta potensi kekuatan nasional dalam mencapai tujuan akhir yaitu terjaganya kedaulatan dan kepentingan Indonesia di Laut Natuna Utara.

Pembangunan kekuatan di Laut China Selatan telah menjadi yang paling aktif dengan berbagai indikator kekuatan, seperti kuantitas dan kualitas senjata yang telah dikerahkan, reklamasi tanah yang dilakukan serta fasilitas militer yang dibangun atau ditingkatkan di pos-pos yang disengketakan. Sebagaimana disampaikan oleh Kepala Sub Direktorat Amerika dan Pasifik, Direktorat Kerjasama Internasional Pertahanan, instalasi struktur pangkalan militer yang telah dibangun China di tiga pulau yaitu, Woody Island, Mischief Reef dan Fiery Cross Island bersifat permanen.

Implikasi dalam merespon hal tersebut ialah berdasarkan Undang-undang RI Nomor 23 Tahun 2019 Tentang Pengelolaan Sumber Daya Nasional Untuk Pertahanan Negara yang menyebutkan tentang pelibatan komponen cadangan dan komponen pendukung dalam mendukung Komponen Utama sebagai bagian dari Pertahanan Negara, pada undang-undang ini juga disebutkan mengenai konsep mobilisasi umum yang akan dilakukan pada saat negara membutuhkan. Karena itu Satuan TNI terintegrasi yang berada di Natuna perlu diperkuat dengan peran serta masyarakat yang ada di Natuna, sebuah ironi jika kita selalu menggaungkan sistem pertahanan rakyat semesta namun tidak pernah menguji sistem tersebut dengan latihan skala besar yang melibatkan komponen cadangan dan komponen pendukung atau masyarakat umum lainnya, sebuah latihan skala besar yang dilaksanakan secara massif di Natuna dengan melibatkan masyarakat Natuna sendiri dapat membuktikan kehandalan sistem pertahanan rakyat semesta jika digunakan secara live, dengan adanya latihan tersebut maka masyarakat Natuna sendiri memiliki kesepahaman jika terjadi perang atau pertempuran di wilayah Natuna, selain itu TNI dapat menguji rantai komando ketika terjadi mobilisasi masal di suatu daerah atau negara apakah dapat berfungsi dengan baik ataukah mengalami kendala-kendala yang hanya dapat diketahui ketika latihan tersebut ada atau pada saat perang dan pertempuran terjadi di Natuna. 


\section{BIBLIOGRAFI}

Arafat, J. (2018). Implementasi Kebijakan Pemerintah Desa Dalam Pengelolaan Sampah Untuk Meningkatkan Pendapatan Asli Desa Dalam Perspektif Ekonomi Islam (Studi pada BUMD Desa Kuta Dalom). UIN Raden Intan Lampung. Google Scholar

Bungin, B. (2007). Penelitian kualitatif: komunikasi, ekonomi, kebijakan publik, dan ilmu sosial lainnya (Vol. 2). Kencana. Google Scholar

Firepower, G. (2020). 2020 Military Strength Ranking. Onlione Elérhetöség: Https://Www. Globalfirepower. Com/Countries-Listing. Asp-Utolsó Letöltés, 8. Google Scholar

Harrison, K., \& Boyd, T. (2018). The role of ideology in politics and society. In Understanding political ideas and movements. Manchester University Press. Google Scholar

Ibrahim, I. S., \& Akhmad, B. A. (2014). Komunikasi dan Komodifikasi: Mengkaji Media dan Budaya dalam Dinamika Globalisasi. Yayasan Pustaka Obor Indonesia. Google Scholar

Lawangan, A. (2019). Hukum Internasional dalam Sorotan Millenial: Kumpulan Tulisan Mahasiswa Program Studi Hukum Keluarga Semester IV Fakultas Syariah IAIN Palopo Tahun 2019. Aksara Timur. Google Scholar

Maksum, A. (2017). Discourses on Islam and democracy in Indonesia: A study on the intellectual debate between Liberal Islam network (JIL) and Hizbut Tahrir Indonesia (HTI). Journal of Indonesian Islam, 11(2), 405-422. Google Scholar

Purba, B., Nainggolan, L. E., Siregar, R. T., Chaerul, M., Simarmata, M. M. T., Bachtiar, E., Rahmadana, M. F., Marzuki, I., \& Meganingratna, A. (2020). Ekonomi Sumber Daya Alam: Sebuah Konsep, Fakta dan Gagasan. Yayasan Kita Menulis. Google Scholar

Raihana, A. (n.d.). Pengaruh Kerjasama Pertahanan India-Vietnam dalam Menghadapi Tiongkok di Sengketa Laut China Selatan (Periode 2014-2016). Jakarta: Fakultas Ilmu Sosial Dan Ilmu Politik UIN Syarif Hidayatullah. Google Scholar

Sinuhaji, J. (2020). Dunia Terisolasi Pandemi Covid-19, Pengguna Twitter Meningkat. PikiranRakyatcom. Diakses Dari Https://Www. Pikiran-Rakyat. Com/Teknologi/Pr- 
Muhammad Achyar, I Wayan Midhio, Khaerudin

01634954/Dunia-Terisolasi-Pandemi-Covid-19-Pengguna-Twitter-Meningkat. Google Scholar

Supriyatno, M. (2014). Tentang ilmu pertahanan. Yayasan Pustaka Obor Indonesia. Google Scholar

Syahriyanto, M. (2021). Implementasi Pendeteksian Similarity Pada Abstrak Jurnal Menggunakan Algoritma Rabin-Karp. Universitas Islam Negeri Sultan Syarif Kasim Riau. Google Scholar

Winarto, K. R. L. (n.d.). Respon Indonesia Menghadapi Ancaman China Di Perairan Natuna. Jurnal Demokrasi Dan Otonomi Daerah, 16(2), 109-144. Google Scholar

First publication right:

Jurnal Syntax Fusion: Jurnal Nasional Indonesia

This article is licensed under:

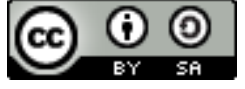

